\title{
Progress of nerve bridges in the treatment of peripheral nerve disruptions
}

\author{
This article was published in the following Dove Press journal: \\ Journal of Neurorestoratology \\ 14 December 2016 \\ Number of times this article has been viewed
}

\section{Qiang Ao}

Department of Tissue Engineering, School of Fundamental Science, China Medical University, Shenyang, Liaoning, Peoples' Republic of China

\section{Correspondence: Qiang Ao}

Department of Tissue Engineering, School of Fundamental Sciences, China Medical University, No 77 Puhe Road, Shenyang North New Area, Shenyang, Liaoning I 10122 , Peoples' Republic of China Tel +86 I35 20245337

Email aoqiang@tsinghua.edu.cn

\begin{abstract}
Clinical repair of a nerve defect is one of the most challenging surgical problems. Autologous nerve grafting remains the gold standard treatment in addressing peripheral nerve injuries that cannot be bridged by direct epineural suturing. However, the autologous nerve graft is not readily available, and the process of harvesting autologous nerve graft results in several complications. Thus, it is necessary to explore an alternative to autologous nerve graft. In the last few decades, with significant advances in the life sciences and biotechnology, a lot of artificial nerve grafts have been developed to aim at the treatment of peripheral nerve disruptions. Artificial nerve grafts range from biological tubes to synthetic tubes and from nondegradable tubes to degradable tubes. Among them, acellular nerve allografts and artificial nerve repair conduits are two kinds of the most promising substitutes for nerve autografts. The history, research status, and prospect of acellular nerve allografts and artificial nerve repair conduits are described briefly in this review.
\end{abstract}

Keywords: peripheral nerve injury, repair, acellular nerve graft, nerve conduit

\section{Introduction}

Peripheral nerve injuries constitute one of the main problems in trauma centers. ${ }^{1,2}$ Treatment of injuries to peripheral nerves is one of the most challenging surgical problems. In cases of simple peripheral nerve disruption, to some extent, functional recovery can be attained through tension-free, end-to-end coaptation of residual nerve stumps. In contrast, trauma and surgical procedures, such as tumor resection, often result in peripheral nerve defects. When the gap between proximal and distal nerve end is large, autologous nerve grafts (autografts) were often clinically used to repair the nerve defect. Autologous nerve grafting remains the gold standard treatment in addressing peripheral nerve injuries that cannot be bridged by direct epineural suturing. ${ }^{3}$ However, the autologous nerve graft is very limited and not readily available, and the process of harvesting autologous nerve graft results in morbidity, such as additional operation injury, recipient nerve difficult to match, donor site denervation, and neuroma formation at the site of harvest, ${ }^{4-6}$ which is like "robbing Peter to pay Paul". Thus, it is necessary to take an alternative to autologous nerve graft to achieve satisfactory functional recovery with little complications, particularly in patients with extensive peripheral nerve injury and insufficient amount of donor nerve for harvest. As a result, a lot of interest has been placed in the development of effective alternatives to nerve autografts in the treatment of peripheral nerve injuries. In the last few decades, researchers have been working to find substitutes for autologous nerve grafts and have 
made great progress. Among them, the most promising and most possible alternatives to autologous nerve grafts were acellular nerve allografts and artificial nerve repair conduits.

\section{Acellular nerve allograft Necessity of acellular nerve allograft}

Allogenic nerve tissue (allografts) is one of the most promising substitutes for nerve autografts due to its similar structure to the autologous nerve. Unfortunately, transplantation of fresh nerve allografts is limited by the concomitant need for systemic immunosuppression, which predisposes graft recipients to opportunistic infections, neoplasia, and toxicity-induced side effects. ${ }^{7,8}$ Studies have confirmed that the main antigen of allogenic nerve present in Schwann cells (SCs) and myelin sheaths and the collagen composition of nerve epineurium, perineurium, and endoneurium have no immunogenicity; the basement membrane has the function of guiding and promoting axon growth in the process of nerve regeneration. ${ }^{9-11}$

Processing nerve allografts to remove cellular components offers an attractive means of circumventing these limitations by reducing graft immunogenicity. The acellular nerve allograft remains a natural neural three-dimensional scaffold structure, which has the advantages of low immunogenicity, no donor area damage, and so on, and thus has been widely studied. Many experiments confirmed that allogeneic nerve graft with appropriate acellular treatment does not cause obvious immune rejection ${ }^{12,13}$; thus, in recent years, many scholars mainly focus on how to reduce the immunogenicity of allografts and as far as possible to retain its natural support structure. Although different processing techniques were explored, all of them simultaneously aim to 1) remove cellular, myelin, and other components of the antigen to reduce the graft immunogenicity and 2) promote the growth of new nerve fibers in the acellular nerve allograft. However, there is little consensus about which processing technique best preserves the natural regenerative capacity of peripheral nerve tissue and maximizes removal of SCs.

\section{Processing techniques of acellular nerve allograft}

Multiple methods exist for preparing acellular nerve grafts from allogenic donor nerve tissue. The processing technique of acellular nerve allograft is the use of chemical, physical, and biological methods to remove allogeneic nerve SCs and myelin, axons, and other ingredients, so that the remaining main components of basement membrane tubes are without damage to repair peripheral nerve defect. At present, a number of methods for peripheral nerve cell removal have been investigated, which are roughly divided into three kinds: physical, chemical, and biological processing techniques (Table 1).

Table I Some processing techniques of acellular nerve allografts

\begin{tabular}{|c|c|c|c|c|c|}
\hline Category & Processing methods & In vitro evaluation & In vivo evaluation & Clinical practice & Shortcomings \\
\hline \multirow[t]{3}{*}{$\begin{array}{l}\text { Physical } \\
\text { methods }\end{array}$} & $\begin{array}{l}\text { Prolonged cold-preservation: } \\
\text { allografts in UW solution at } \\
4^{\circ} \mathrm{C} \text { for } 3 \text { weeks }\end{array}$ & $\begin{array}{l}\text { Effectively eliminate the } \\
\text { antigenicity of peripheral } \\
\text { nerve allografts and } \\
\text { conserve native SC } \\
\text { basal laminae and nerve } \\
\text { ECM }^{14-16}\end{array}$ & $\begin{array}{l}\text { Enable robust axonal } \\
\text { regeneration through } \\
\text { transplanted acellular } \\
\text { allografts }^{16}\end{array}$ & NA & $\begin{array}{l}\text { Clinical application of cold } \\
\text { preservation techniques } \\
\text { has remained limited due } \\
\text { to extended processing } \\
\text { times ( } ~ 7 \text { weeks) } \\
\text { and poor mechanical } \\
\text { properties of these friable } \\
\text { acellular grafts }{ }^{17}\end{array}$ \\
\hline & $\begin{array}{l}\text { Freeze-thawing: by quickly } \\
\text { repeated freezing and } \\
\text { thawing tissue, making cell } \\
\text { membranes rupture, and } \\
\text { causing cell lysis }\end{array}$ & $\begin{array}{l}\text { By controlling the } \\
\text { rate of temperature } \\
\text { change, preventing } \\
\text { the structure of the } \\
\text { basement membrane } \\
\text { from destruction by } \\
\text { formation of ice crystals } \\
\text { within the cells }{ }^{13}\end{array}$ & $\begin{array}{l}\text { Longest distance of neural } \\
\text { repair by acellular nerve } \\
\text { allograft treated with } \\
\text { freeze-thawing is } 2-4 \mathrm{~cm}^{18,19}\end{array}$ & NA & $\begin{array}{l}\text { More fractures exist } \\
\text { in neural basement } \\
\text { membrane by freeze- } \\
\text { thawing process, and } \\
\text { these broken structures } \\
\text { facilitate infiltration of } \\
\text { lymphocytes } 13,20\end{array}$ \\
\hline & $\begin{array}{l}\text { Lyophilization: freeze-drying } \\
\text { technique is used to freeze } \\
\text { allograft nerve into a solid } \\
\text { state at lower temperatures, } \\
\text { which is then sublimated } \\
\text { directly into gas, and finally } \\
\text { cause nerve dehydration }\end{array}$ & $\begin{array}{l}\text { Has a larger porosity } \\
\text { and pore diameter, } \\
\text { and it is possible that } \\
\text { this is conducive to the } \\
\text { adhesion and growth of } \\
\text { cells }^{21}\end{array}$ & $\begin{array}{l}\text { Although animal experiments } \\
\text { confirmed that the freeze- } \\
\text { dried nerves could repair } \\
\text { peripheral nerve defects, } \\
\text { some scholars believe that this } \\
\text { kind of allograft could not well } \\
\text { promote nerve regeneration }{ }^{18}\end{array}$ & NA & $\begin{array}{l}\text { After freeze-drying } \\
\text { treatment, SCs of } \\
\text { treated nerve still have } \\
\text { part of the activity, } \\
\text { with somewhat } \\
\text { immunogenicity }{ }^{21}\end{array}$ \\
\hline
\end{tabular}


Table I (Continued)

\begin{tabular}{|c|c|c|c|c|c|}
\hline Category & Processing methods & In vitro evaluation & In vivo evaluation & Clinical practice & Shortcomings \\
\hline \multirow[t]{4}{*}{$\begin{array}{l}\text { Chemical } \\
\text { methods }\end{array}$} & $\begin{array}{l}\text { Detergent processing: } \\
\text { early protocols relied } \\
\text { heavily on the use of } \\
\text { sodium deoxycholate, Triton } \\
\text { X-100, and deionized water } \\
\text { to decellularize nerve } \\
\text { grafts } \\
15,22\end{array}$ & $\begin{array}{l}\text { Morphological } \\
\text { observations } \\
\text { demonstrate that } \\
\text { all cells and myelin } \\
\text { basic structures were } \\
\text { cleared, and the nerve } \\
\text { basal lamina structure } \\
\text { was intact }{ }^{23}\end{array}$ & $\begin{array}{l}\text { Its regenerative axon } \\
\text { density was significantly } \\
\text { higher than the acellular } \\
\text { allografts treated with } \\
\text { freeze-thaw method }\end{array}$ & NA & $\begin{array}{l}\text { Basement membrane } \\
\text { retention methods need } \\
\text { to be improved }\end{array}$ \\
\hline & $\begin{array}{l}\text { Detergent processing: } \\
\text { nerve allografts were } \\
\text { repeatedly exposed to } \\
\text { solutions of deionized } \\
\text { water, SB- } 10 \text {, and Triton } \\
\text { X-200/SB-16 over a period } \\
\text { of } 4 \text { days }^{24}\end{array}$ & $\begin{array}{l}\text { Superior preservation } \\
\text { of native ECM and } \\
\text { equivalent levels } \\
\text { of decellularization } \\
\text { compared to previous } \\
\text { chemical processing } \\
\text { techniques }^{24}\end{array}$ & $\begin{array}{l}\text { Having been shown to } \\
\text { support significantly greater } \\
\text { densities of regenerating } \\
\text { axons than both thermally } \\
\text { decellularized and chemically } \\
\text { decellularized nerve } \\
\text { allografts when implanted in } \\
\text { rat sciatic nerve }\end{array}$ & NA & $\begin{array}{l}\text { More effectively retain } \\
\text { the basal lamina structure }\end{array}$ \\
\hline & $\begin{array}{l}\text { AxoGen }{ }^{\circledR} \text {-processed nerves } \\
\text { are known to undergo a } \\
\text { combination of treatments, } \\
\text { including chemical } \\
\text { decellularization (detergent } \\
\text { processing), gamma } \\
\text { irradiation, and enzymatic } \\
\text { digestion of CSPG }\end{array}$ & $\begin{array}{l}\text { Differences in washing } \\
\text { time could have } \\
\text { differential effects on } \\
\text { the integrity of the ECM } \\
\text { within donor nerves }{ }^{17}\end{array}$ & $\begin{array}{l}\text { AxoGen-processed } \\
\text { nerve grafts in rats were } \\
\text { unexpectedly observed to } \\
\text { facilitate lesser degrees } \\
\text { of functional nerve } \\
\text { regeneration compared to } \\
\text { detergent-processed nerve } \\
\text { allografts }^{17}\end{array}$ & $\begin{array}{l}\text { Successfully } \\
\text { applied in a clinical } \\
\text { setting }\end{array}$ & $\begin{array}{l}\text { Reduced regenerative } \\
\text { capacity of AxoGen- } \\
\text { processed nerve grafts } \\
\text { may result from the } \\
\text { optimization of the } \\
\text { AxoGen decellularization } \\
\text { techniques for use with } \\
\text { human nerve tissue, } \\
\text { rather than rodent }^{17}\end{array}$ \\
\hline & $\begin{array}{l}\text { An hANG as an alternative } \\
\text { to autogenous nerve } \\
\text { commercially named } \\
\text { "Shenqiao" }\end{array}$ & $\begin{array}{l}\text { The scaffolds were cell } \\
\text { free and rich in collagen } \\
\text { I and laminin, with } \\
\text { a microarchitecture } \\
\text { similar to the fibrous } \\
\text { framework of human } \\
\text { peripheral nerves }\end{array}$ & $\begin{array}{l}\text { Results of clinical trials } \\
\text { showed that its efficacy } \\
\text { in restoring digital nerve } \\
\text { function was similar to that of } \\
\text { other materials on the market, } \\
\text { suggesting that it is both safe } \\
\text { and effective }\end{array}$ & $\begin{array}{l}\text { Restoring digital } \\
\text { nerve function in } \\
\text { clinic }\end{array}$ & $\begin{array}{l}\text { The patients of this } \\
\text { study did not receive } \\
\text { sensory reeducation, and } \\
\text { maximum follow-up time } \\
\text { was only } 6 \text { months }\end{array}$ \\
\hline \multirow[t]{2}{*}{$\begin{array}{l}\text { Biological } \\
\text { methods }\end{array}$} & $\begin{array}{l}\text { Enzyme digestion methods: } \\
\text { enzymes currently mainly } \\
\text { used were trypsin and } \\
\text { nuclease }\end{array}$ & $\begin{array}{l}\text { Generally, enzyme } \\
\text { digestion was applied } \\
\text { using physical or } \\
\text { chemical methods, to } \\
\text { assist in the destruction } \\
\text { of the engagement } \\
\text { between the cell } \\
\text { membrane and the } \\
\text { basement membrane }{ }^{26}\end{array}$ & NA & NA & $\begin{array}{l}\text { Need to be combined } \\
\text { with a physical or } \\
\text { chemical method }\end{array}$ \\
\hline & $\begin{array}{l}\text { Chondroitinase } A B C \text { : } \\
\text { chondroitinase } A B C \text { can } \\
\text { degrade nerve CSPGs, which } \\
\text { is believed to impede axonal } \\
\text { regeneration }{ }^{27,28}\end{array}$ & NA & $\begin{array}{l}\text { Experiments confirmed that } \\
\text { nerve allografts treated by } \\
\text { chondroitinase } A B C \text { could } \\
\text { promote the regeneration of } \\
\text { peripheral nerve and reduce } \\
\text { the generation of scar }{ }^{29-31}\end{array}$ & NA & $\begin{array}{l}\text { Need to be combined } \\
\text { with a physical or } \\
\text { chemical method }\end{array}$ \\
\hline
\end{tabular}

Abbreviations: UW, University of Wisconsin; SC, Schwann cell; ECM, extracellular matrix; NA, not applicable; SB-10, sulfobetaine-10; SB-16, sulfobetaine-16; CSPG, chondroitin sulfate proteoglycan; hANG, human acellular nerve graft.

\section{Artificial nerve repair conduits Advantages of nerve repair conduits}

Nerve repair conduit is another alternative to nerve autograft. In nerve conduit bridging technique, proximal and distal nerve stumps are inserted into the two ends of a nerve conduit, and axons regenerating from the proximal stump grow through the conduit and selectively grow into their original pathways in the distal stump. The conduit provides trophic support for both stumps and prevents the invasion of the surrounding tissues into the gap between the two stumps. 
Moreover, nerve conduits enrich the neurotrophic factors within the chamber and build a microenvironment, which enhances axonal regeneration after injury. ${ }^{32}$

The ideal nerve repair conduits should possess the following features: 1) the diameter could be adjusted to accommodate repairing nerves of different diameters; 2 ) the length should be adjusted freely, to avoid anastomotic tension and ensure simple operation; 3 ) preventing the invasion of scar tissue outside and guide axonal growth in orientation; 4) ensuring that endogenous neuroactive molecules aggregate and exclude exogenous inhibitory molecules outside the conduits; and 5) the most important is they should avoid the suffering from nerve autograft.

\section{Material research of nerve repair conduit}

Nerve repair conduits can be divided into biological and synthetic nerve conduits.

\section{Biological conduits}

Biological conduits such as autologous arteries, veins, muscles, ${ }^{33}$ and umbilical cord vessels have been widely used to repair relatively short nerve defects. These materials can provide support for the nerve in the short term and degrade to innocuous products after complete nerve regeneration. Some authors have used autogenetic epineurium, ${ }^{34,35}$ autogenic veins and autogenic small arteries, and even muscle fibers $^{36-40}$ to repair peripheral nerve injury and reported satisfying results.

\section{Synthetic nerve conduits}

Synthetic nerve conduits include nondegradable and degradable nerve conduits.

\section{Nondegradable nerve conduits}

Nondegradable nerve conduits include silicone, plastic, and polytetrafluoroethylene tubes. The silica gel canal was the earliest artificial conduit. ${ }^{41,42}$ Lundborg et a ${ }^{41}$ used silicon tubes to repair nerve defects. ${ }^{1}$ Hollow silicon tubes have been used to repair $<1 \mathrm{~cm}$ long nerve defects in rat sciatic nerve, ${ }^{43}$ and silicone tubes filled with SCs have been used to repair a $1.5 \mathrm{~cm}$ defect in rat sciatic nerve. ${ }^{44}$ Although nondegradable nerve conduits eliminated the need to harvest autologous nerves, they always cause inflammation of the surrounding tissues and compression of nerve that could affect the regeneration of nerve axons. ${ }^{45}$ Another disadvantage of these conduits is that they require a second surgery for removal, which could cause pain and more injury to the patient.

\section{Degradable nerve conduits}

The commonly used degradable materials include collagen, ${ }^{46,47}$ chitin, ${ }^{48,49}$ polyglycolic acid (PGA), polylactic acid (PLA), glycolide, trimethylene carbonate, ${ }^{50}$ etc.

Rosen et al compared autologous nerve graft and PGA conduit to bridge $5 \mathrm{~mm}$ defects in rat femoral nerve. After 11 months, autologous nerve graft was found to be superior to PGA grafting only by means of axonal diameter, but having no difference by means of axonal count or electrophysiologic or functional characteristics between the techniques. ${ }^{51}$ den Dunnen et al used poly(DL-lactide-epsilon-caprolactone) nerve guides and autologous nerve grafts to repair rat sciatic nerve defects. Application of biodegradable nerve conduits resulted in faster and qualitatively better nerve regeneration across a short nerve gap $(1 \mathrm{~cm})$ than with the autologous nerve grafting method. ${ }^{52}$

\section{Techniques and methods for processing nerve conduits}

Physical structures of nerve conduits significantly affect their performance. Processing methods of the nerve conduits mainly include solution casting - impregnated particles filtered out technology, melt injection - particles filtered out technology, solvent evaporation technique, physical roll film technology, weaving techniques, and the electrospinning technology. However, hollow biodegradable materials can be used to repair only relatively short nerve defects, and the functional recovery is still not satisfying. The combined use of fibronectin mats, ${ }^{53}$ allogeneic SCs, ${ }^{54,55}$ ectogenous neurotrophic factors, and bridging tubes was proved to enhance neural regeneration after the injury. ${ }^{56}$ Thus, the aim should be to mimic the natural repair process after nerve injury using a variety of techniques and methods to build complex nerve conduit that will integrate several factors to promote nerve regeneration within the conduit. ${ }^{57}$ The methods of biomedical nanotechnology, electrospinning technology, and tissue engineering are able to develop new ways for these new conduits possessing good electrical, mechanical, and biological characteristics, which are beneficial to the axon guidance and the promotion of nerve regeneration.

\section{Clinical application of nerve repair conduits}

In the last several decades, nerve conduits have been used in clinical practice and have successfully improved the functional recovery after peripheral nerve injury. ${ }^{58-61}$ The current clinical applications of such materials are thus 
Table 2 Nerve repair conduits approved by the FDA

\begin{tabular}{|c|c|c|c|c|}
\hline Product name & Material & Diameter $\times$ length & Degradation time & Company \\
\hline Neurotube $^{\mathrm{TM}}$ & PGA & $2-8 \mathrm{~mm} \times 4 \mathrm{~cm}$ & 3 months & $\begin{array}{l}\text { Synovis Micro } \\
\text { Companies Alliance, } \\
\text { Birmingham, AL, USA }\end{array}$ \\
\hline $\begin{array}{l}\text { NeuroMatrix }{ }^{\mathrm{TM}}, \\
\text { Neuroflex }^{\mathrm{TM}}\end{array}$ & Type I collagen & $2-6 \mathrm{~mm} \times 2.5 \mathrm{~cm}$ & 7 months & $\begin{array}{l}\text { Collagen Matrix Inc., } \\
\text { Franklin Lakes, NJ, USA }\end{array}$ \\
\hline Neurolac $^{\circledR}$ & Poly(DL-lactide-caprolactone) & $1.5-10 \mathrm{~mm} \times 3 \mathrm{~cm}$ & 16 months & $\begin{array}{l}\text { Polyganics BV, } \\
\text { Groningen, the } \\
\text { Netherlands }\end{array}$ \\
\hline Neuragen $^{\circledR}$ & Type I collagen & $2-7 \mathrm{~mm} \times 2 \mathrm{~cm}$ & 4 years & $\begin{array}{l}\text { Integra Neuroscience, } \\
\text { Plainsboro, NJ, USA }\end{array}$ \\
\hline SaluBridge ${ }^{\circledR}$ & Polyvinyl alcohol hydrogel & $2-10 \mathrm{~mm} \times 6.35 \mathrm{~cm}$ & No degradation & $\begin{array}{l}\text { SaluMedica LLC, } \\
\text { Atlanta, GA, USA }\end{array}$ \\
\hline
\end{tabular}

Abbreviations: FDA, US Food and Drug Administration; PGA, polyglycolic acid.

mainly limited to treating small peripheral sensory nerve defects. These applications primarily use the type I collagen conduit Neuragen ${ }^{\circledR}$, the PGA and PLA conduit Neurotube ${ }^{\mathrm{TM}}$, and the PCL copolymer conduit Neurolac ${ }^{\circledR}$ for nerve defects of $£ 20 \mathrm{~mm},{ }^{62}$ and both types of tubes (biological and synthetic) have led to good clinical results, ${ }^{63}$ even if they could not reach the effect level of autologous nerve repair. On the other hand, treatment of large-diameter, long-distance nerve regeneration remains the biggest challenge faced by the researchers in this field. Table 2 lists some nerve repair conduits approved by the US Food and Drug Administration (FDA) in the world.

\section{Conclusion}

Acellular nerve allografts and artificial nerve repair conduits are two kinds of the most promising substitutes for nerve autografts, and some products of both of them were approved by the FDA (US and China). The functionality of acellular nerve allografts was better than the artificial nerve repair conduits, due to the natural basal lamina structure of the former, which displays much more efficiency in the repair of longer nerve defects. However, nerve repair conduits possess some merits, eg, easy operation, readily available, low cost, and especially suitable for the repair of small gaps of nerve defects. Although significant progress was achieved in both kinds of the products, they could only repair a shorter length of nerve defect, comparing with autologous nerve graft, and the repair functionality needs to be improved. With technological advances in the life sciences and biotechnology, it is believed that better nerve repair products will come out in the near future.

\section{Disclosure}

The author reports no conflicts of interest in this work.

\section{References}

1. Nectow AR, Marra KG, Kaplan DL. Biomaterials for the development of peripheral nerve guidance conduits. Tissue Eng Part B Rev. 2011; 18(1):40-50.

2. Taylor CA, Braza D, Rice JB, Dillingham T. The incidence of peripheral nerve injury in extremity trauma. Am J Phys Med Rehabil. 2008; 87(5):381-385.

3. Ducic I, Fu R, Iorio ML. Innovative treatment of peripheral nerve injuries: combined reconstructive concepts. Ann Plast Surg. 2012;68(2): 180-187.

4. Hussain M, Huang W, Priestley J. The regenerative potential of fullydegummed silk conduits in peripheral nerve injury repair compared to the current 'gold standard' of autologous graft repair. Int J Surg. 2013; 11(8):591-591.

5. Staniforth $P$, Fisher TR. The effects of sural nerve excision in autogenous nerve grafting. Hand. 1978;10(2):187-190.

6. Ortiguela ME, Wood MB, Cahill DR. Anatomy of the sural nerve complex. J Hand Surg Am. 1987;12(6):1119-1123.

7. Mackinnon SE, Novak CB. Nerve transfers. New options for reconstruction following nerve injury. Hand Clin. 1999;15(4):643-666.

8. Porayko MK, Textor SC, Krom RA, et al. Nephrotoxic effects of primary immunosuppression with FK-506 and cyclosporine regimens after liver transplantation. Mayo Clin Proc. 1994;69(2):105-111.

9. Gulati AK. Immunological fate of Schwann cell-populated acellular basal lamina nerve allografts. Transplantation . 1995;59(11):1618-1622.

10. Ide C, Osawa T, Tohyama K. Nerve regeneration through allogeneic nerve grafts with special reference to the role of the Schwann cell basal lamina. Prog Neurobiol. 1990;34(1):1-38.

11. Tajima K, Tohyama K, Ide C, Abe M. Regeneration through nerve allografts in the cynomolgus monkey (Macaca fascicularis). J Bone Joint Surg Am. 1991;73(2):172-185.

12. Hess JR, Brenner MJ, Fox IK, et al. Use of cold-preserved allografts seeded with autologous Schwann cells in the treatment of a long-gap peripheral nerve injury. Plast Reconstr Surg. 2007;119(1):246-259.

13. Hudson TW, Zawko S, Deister C, et al. Optimized acellular nerve graft is immunologically tolerated and supports regeneration. Tissue Eng. 2004;10(11-12):1641-1651.

14. Fox IK, Jaramillo A, Hunter DA, Rickman SR, Mohanakumar T, Mackinnon SE. Prolonged cold-preservation of nerve allografts. Muscle Nerve. 2005;31(1):59-69.

15. Evans PJ, Mac Kinnon SE, Midha R, et al. Regeneration across cold preserved peripheral nerve allografts. Microsurgery. 1999;19(3):115-127.

16. Evans PJ, Mackinnon SE, Best TJ, et al. Regeneration across preserved peripheral nerve grafts. Muscle Nerve. 1995;18(10):1128-1138.

17. Moore AM, Mac Ewan M, Santosa KB, et al. Acellular nerve allografts in peripheral nerve regeneration: a comparative study. Muscle Nerve. 2011;44(2):221-234. 
18. Nadim W, Anderson PN, Turmaine M. The role of Schwann cells and basal lamina tubes in the regeneration of axons through long lengths of freeze-killed nerve grafts. Neuropathol Appl Neurobiol. 1990; 16(5):411-421.

19. Hall SM. The effect of inhibiting Schwann cell mitosis on the reinnervation of acellular autografts in the peripheral nervous system of the mouse. Neuropathol Appl Neurobiol. 1986;12(4):401-414.

20. Osawa T, Tohyama K, Ide C. Allogeneic nerve grafts in the rat, with special reference to the role of Schwann cell basal laminae in nerve regeneration. J Neurocytol. 1990;19(6):833-849.

21. Gulati AK, Cole GP. Immunogenicity and regenerative potential of acellular nerve allografts to repair peripheral nerve in rats and rabbits. Acta Neurochir (Wien). 1994;126(2-4):158-164.

22. Levi AD, Evans PJ, Mackinnon SE, Bunge RP. Cold storage of peripheral nerves: an in vitro assay of cell viability and function. Glia. 1994;10(2):121-131.

23. Sondell M, Lundborg G, Kanje M. Regeneration of the rat sciatic nerve into allografts made acellular through chemical extraction. Brain Res. 1998;795(1-2):44-54.

24. Evans PJ, Mackinnon SE, Levi AD, et al. Cold preserved nerve allografts: changes in basement membrane, viability, immunogenicity, and regeneration. Muscle Nerve. 1998;21(11):1507-1522.

25. Strasberg SR, Hertl MC, Mackinnon SE, et al. Peripheral nerve allograft preservation improves regeneration and decreases systemic cyclosporin A requirements. Exp Neurol. 1996;139(2):306-316.

26. Dumont CE, Hentz VR. Enhancement of axon growth by detergentextracted nerve grafts. Transplantation. 1997;63(9):1210-1215.

27. Snow DM, Lemmon V, Carrino DA, Caplan AI, Silver J. Sulfated proteoglycans in astroglial barriers inhibit neurite outgrowth in vitro. Exp Neurol. 1990;109(1):111-130.

28. Zuo J, Neubauer D, Dyess K, Ferguson TA, Muir D. Degradation of chondroitin sulfate proteoglycan enhances the neurite-promoting potential of spinal cord tissue. Exp Neurol. 1998;154(2):654-662.

29. Neubauer D, Graham JB, Muir D. Chondroitinase treatment increases the effective length of acellular nerve grafts. Exp Neurol. 2007; 207(1):163-170.

30. Krekoski CA, Neubauer D, Zuo J, Muir D. Axonal regeneration into acellular nerve grafts is enhanced by degradation of chondroitin sulfate proteoglycan. J Neurosci. 2001;21(16):6206-6213.

31. Alilain WJ, Horn KP, Hu H, Dick TE, Silver J. Functional regeneration of respiratory pathways after spinal cord injury. Nature. 2011;475(7355):196-200.

32. Roam JL, Yan Y, Nguyen PK, et al. A modular, plasmin-sensitive, clickable poly(ethyleneglycol)-heparin-laminin microsphere system for establishing growth factor gradients in nerve guidance conduits. Biomaterials. 2015;72:112-124.

33. Dornseifer ULF, Fichter AM, Leichtle S, et al. Peripheral nerve reconstruction with collagen tubes filled with denatured autologous muscle tissue in the rat model. Microsurgery. 2011;31(8):632-641.

34. Chiu DT, Janecka I, Krizek TJ, Wolff M, Lovelace RE. Autogenous vein graft as a conduit for nerve regeneration. Surgery. 1982;91(2):226-233.

35. Siemionow M, Demir Y, Mukherjee AL. Repair of peripheral nerve defects with epineural sheath grafts. Ann Plast Surg. 2010;65(6): 546-554.

36. Yuksel F, Ulkur E, Baloglu H, Celikoz B. Nerve regeneration through a healthy peripheral nerve trunk as a nerve conduit: a preliminary study of a new concept in peripheral nerve surgery. Microsurgery. 2002;22(4):138-143.

37. Tos $\mathrm{P}$, Battiston B, Ciclamini D, Geuna S, Artiaco S. Primary repair of crush nerve injuries by means of biological tubulization with musclevein-combined grafts. Microsurgery. 2012;32(5):358-363.

38. De Stefano ME, Toni F, D'Orazi V, et al. Therapeutic approaches enhancing peripheral nerve regeneration. Adv Biosci Biotechnol. 2013; 4:53.

39. Sun F, Zhou K, Mi WJ, Qiu JH. Combined use of decellularized allogeneic artery conduits with autologous transdifferentiated adiposederived stem cells for facial nerve regeneration in rats. Biomaterials. 2011;32(32):8118-8128.
40. Wang X, Luo E, Li Y, Hu J. Schwann-like mesenchymal stem cells within vein graft facilitate facial nerve regeneration and remyelination. Brain Res. 2011;1383:71-80.

41. Lundborg G, Dahlin LB, Danielsen N, et al. Nerve regeneration in silicone chambers: influence of gap length and of distal stump components. Exp Neurol. 1982;76(2):361-375.

42. Williams LR, Powell HC, Lundborg G, Varon S. Competence of nerve tissue as distal insert promoting nerve regeneration in a silicone chamber. Brain Res. 1984;293(2):201-211.

43. Timmer M, Robben S, MuIIer-Ostermeyer F, et al. AxonaI regeneration across long gaps in silicone chambers filled with Schwann cells overexpressing high molecular weight FGF-2. Cell Transplant. 2003;12(3):265-277.

44. Lundborg G, Dahlin LB, Danielsen NP, Hansson HA, Larsson K. Reorganization and orientation of regenerating nerve fibres, perineurium, and epineurium in preformed mesothelial tubes - an experimental study on the sciatic nerve of rats. $J$ Neurosci Res. 1981;6(3): 265-281.

45. Lundborg G, Dahlin L, Dohi D, Kanje M, Terada N. A new type of "bioartificial" nerve graft for bridging extended defects in nerves. J Hand Surg Br. 1997;22(3):299-303.

46. Wangensteen KJ, Kalliainen LK. Collagen tube conduits in peripheral nerve repair: a retrospective analysis. Hand. 2010;5(3):273-277.

47. Riccio M, Pangrazi PP, Parodi PC, et al. The amnion muscle combined graft (AMCG) conduits: a new alternative in the repair of wide substance loss of peripheral nerves. Microsurgery. 2014;34(8):616-622.

48. Zhang P, Xue F, Kou Y, et al. The experimental study of absorbable chitin conduit for bridging peripheral nerve defect with nerve fasciculu in rats. Artif Cells Blood Substit Immobil Biotechnol. 2008;36(4): 360-371.

49. Wang W, Itoh S, Matsuda A, et al. Enhanced nerve regeneration through a bilayered chitosan tube: the effect of introduction of glycine spacer into the CYIGSR sequence. J Biomed Mater Res A. 2008;85(4): 919-928.

50. Xie F, Li QF, Gu B, Liu K, Shen GX. In vitro and in vivo evaluation of a biodegradable chitosan-PLA composite peripheral nerve guide conduit material. Microsurgery. 2008;28(6):471-479.

51. Rosen JM, Padilla JA, Nguyen KD, Padilla MA, Sabelman EE, Pham HN. Artificial nerve graft using collagen as an extracellular matrix for nerve repair compared with sutured autograft in a rat model. Ann Plast Surg. 1990;25(5):375-387.

52. den Dunnen WF, van der Lei B, Schakenraad JM, et al. Poly(DL-lactideepsilon-caprolactone) nerve guides perform better than autologous nerve grafts. Microsurgery. 1996;17(7):348-357.

53. Gonzalez-Perez F, Udina E, Navarro X. Extracellular matrix components in peripheral nerve regeneration. Int Rev Neurobiol. 2013;108: 257-275.

54. Brown RE, Erdmann D, Lyons SF, Suchy H. The use of cultured Schwann cells in nerve repair in a rabbit hind-limb model. J Reconstr Microsurg. 1996;12(3):149-152.

55. Rodrigues MC, Rodrigues AA Jr, Glover LE, Voltarelli J, Borlongan CV. Peripheral nerve repair with cultured Schwann cells: getting closer to the clinics. Sci World J. 2012;2012:413091.

56. Gordon T. Neurotrophic factor expression in denervated motor and sensory Schwann cells: relevance to specificity of peripheral nerve regeneration. Exp Neurol. 2014;254:99.

57. Koudehi MF, Fooladi AA, Mansoori K, Jamalpoor Z, Amiri A, Nourani MR. Preparation and evaluation of novel nano-bioglass/gelatin conduit for peripheral nerve regeneration. J Mater Sci Mater Med. 2014;25(2):363-373.

58. Lee JY, Giusti G, Friedrich PF, et al. The effect of collagen nerve conduits filled with collagen-glycosaminoglycan matrix on peripheral motor nerve regeneration in a rat model. J Bone Joint Surg Am. 2012;94(22):2084-2091.

59. Gu J, Hu W, Deng A, Zhao Q, Lu S, Gu X. Surgical repair of a $30 \mathrm{~mm}$ long human median nerve defect in the distal forearm by implantation of a chitosan-PGA nerve guidance conduit. J Tissue Eng Regen Med. 2012;6(2):163-168. 
60. Ignatiadis IA, Yiannakopoulos CK, Avram AM, Gerostathopoulos NE. Posttraumatic neuroma of the radial nerve treated with an autogenous epineural conduit technique. A case report. Microsurgery. 2009;29(2):133-135.

61. Tseng CY, Hu G, Ambron RT, Chiu DTW. Histologic analysis of Schwann cell migration and peripheral nerve regeneration in the autogenous venous nerve conduit (AVNC). J Reconstr Microsurg. 2003;19(5):331-340.
62. Kehoe S, Zhang XF, Boyd D. FDA approved guidance conduits and wraps for peripheral nerve injury: a review of materials and efficacy. Injury. 2012;43(5):553-572.

63. Battiston B, Geuna S, Ferrero M, Tos P. Nerve repair by means of tubulization: literature review and personal clinical experience comparing biological and synthetic conduits for sensory nerve repair. Microsurgery. 2005;25(4):258-267.

\section{Publish your work in this journal}

The Journal of Neurorestoratology is an international, peer-reviewed, open access online journal publishing original research and review articles on the subject of Neurorestoratology. To provide complete coverage of this revolutionary field the Journal of Neurorestoratology will report on relevant experimental research, technological advances,

\section{Dovepress}

and clinical achievements. The manuscript management system is completely online and includes a very quick and fair peer-review system, which is all easy to use. Visit http://www.dovepress.com/testimonials. php to read real quotes from published authors. 